Lagodienko Natalia, Ph.D. (Economics), Senior Lecturer, Mykolayiv National Agrarian University, Mykolayiv, Ukraine

ORCID ID: 0000-0003-3528-0519

e-mail: besedina77@gmail.com

Palamarchuk Victoriia, Applicant of Higher Education, Accounting and Finance Faculty, Mykolayiv National Agrarian University, Mykolayiv, Ukraine

ORCID ID: 0000-0002-6466-6835

e-mail: palamar98@ukr.net

Hamaiun Vladyslav, Applicant of Higher Education, Accounting and Finance Faculty, Mykolayiv National Agrarian University, Mykolayiv, Ukraine

e-mail: Ja3aR1@gmail.com

\title{
Monitoring the Impact of Tax Avoidance on the State Budget of Ukraine
}

Abstract. Introduction. Due to unstable economic situation in the country, the constant state budget deficit, the high level of the shadow economy in Ukraine and the crisis in the world, it is necessary to develop effective mechanisms to combat tax evasion, improve tax legislation and reform the tax system. The level of tax evasion in Ukraine tends to increase steadily. Therefore, there is a need to study the problem of tax evasion in Ukraine and its impact on the economy.

Purpose. The main purpose of the study is to monitor the impact of tax evasion on the state budget of Ukraine.

Results. The impact of tax evasion on the state budget of Ukraine in the conditions of unstable economic situation was monitored. The regulatory framework of Ukraine on tax evasion is indicated. Schematically presents the composition of a criminal offense - tax evasion. The dynamics of revenues of the state and consolidated budgets of Ukraine are presented. The dynamics of tax revenues to the state and consolidated budgets of Ukraine is analyzed. The average indicators of revenues of the state and consolidated budgets, the average indicators of the share of tax revenues in the total revenues of the state and consolidated budgets of Ukraine during the study period are calculated. The main schemes of tax evasion in Ukraine and conditional losses from them for the state budget are studied. The level of tax burden in the state is determined and its dynamics are presented. It has been proven that tax evasion has a negative impact on Ukraine's economy.

Conclusions. We are convinced that the introduction of effective mechanisms to combat tax evasion, adaptation to modern conditions of digitalization, improvement and updating of tax legislation, increasing trust between taxpayers and the state, combating bureaucracy and corruption, reforming the tax system - all this will help educate Ukrainian citizens. tax responsible population, minimize opportunities for tax evasion, reduce accounts payable and the impact of creditors on the economy and political situation in the country, improve economic performance in the country, increase the level of economic and national security of Ukraine.

Keywords: tax; collection; tax evasion; budget; shadow economy.

\section{удк 339.5}

Лагодієнко Н. В., кандидат економічних наук, доцент кафедри обліку і оподаткування, Миколаївський національний аграрний університет, м. Миколаїв, Україна

Паламарчук В. Ю., здобувач вищої освіти обліково-фінансового факультету, Миколаївський національний аграрний університет, м. Миколаїв, Україна

Гамаюн В. В., здобувач вищої освіти обліково-фінансового факультету, Миколаївський національний аграрний університет, м. Миколаїв, Україна

\section{Моніторинг впливу ухилення від оподаткування на державний бюджет України}

Анотація. В умовах нестабільної економічної ситуації в країні, постійного дефіциту державного бюджету, високого рівня тіньової економіки в Україні та кризової ситуації у світі необхідно розробити ефективні механізми боротьби з ухиленням від оподаткування, вдосконалити податкове законодавство, реформувати податкову систему. Рівень ухилень від оподаткування в Україні має тенденцію до постійного зростання. Тому існує необхідність в дослідженні проблеми ухилення від оподаткування в Україні та їі вплив на економіку держави. У статті проведено моніторинг впливу ухилення від оподаткування на державний бюджет України в умовах нестабільної економічноі ситуації. Зазначено нормативну базу України з питань ухилення від оподаткування. Схематично представлено склад кримінального злочину - ухилення від оподаткування. Представлено динаміку доходів державного та зведеного бюджетів України. Проаналізовано динаміку податкових надходжень до державного та зведеного бюджетів України. Розраховано середні показники доходів державного та зведеного бюджетів, середні показники питомої ваги податкових 
надходжень в сукупних доходах державного та зведеного бюджетів України протягом досліджуваного періоду. Досліджено основні схеми ухилення від оподаткування в Україні та умовні втрати від них для державного бюджету. Визначено рівень податкового навантаження в державі та представлено його динаміку. Доведено, що ухилення від оподаткування здійснює негативний вплив на економіку Украйни: найбільше втрат для державного бюджету завдають: «сірий імпорт», контрабанда (70 млрд грн) та офшорні схеми (65 млрд грн). Всього державний бюджет втрачає тільки через зазначені основні види схем ухилення від оподаткування 181 млрд грн за рік. Розрахунок рівня податкового навантаження в Україні та його динаміка за період 2014-2019 рр. довели, що у звітному 2019 р. розрахований показник збільшився у порівнянні з базовим 2014 р. на 3,47 \%. У цілому протягом даного періоду показник займає в середньому майже чверть обсягу номінального ВВП.

Ключові слова: податок; збір; ухилення від оподаткування; бюджет; тіньова економіка.

Problem statement. Given the unstable economic situation in the country, the constant state budget deficit, the high level of the shadow economy in Ukraine and the crisis in the world, it is necessary to develop effective mechanisms to combat tax evasion, improve tax legislation and reform the tax system. The level of tax evasion in Ukraine tends to increase steadily. Therefore, there is a need to study the problem of tax evasion in Ukraine and its impact on the economy.

Analysis of recent research and publications. Many scientists have studied the problem of tax evasion in Ukraine in their works: V. Dubrovsky [1], O. Zamaslo, N. Zubik [3], T. Koryagina, K. Yakymenko [5], O. Kramarenko [6], O. Melnyk [8], Y. Yakymchuk [13] and others.

Given the unstable economic situation in Ukraine, the high level of tax evasion, the negative impact of the global crisis and the crisis caused by the spread of the COVID-19 pandemic on the economy, consideration of this topic is relevant.

Formulation of research objectives. The main purpose of the study is to monitor the impact of tax evasion on the state budget of Ukraine.

Presentation of the main research material. According to Article 6 of the Tax Code of Ukraine, the tax is a "mandatory, unconditional payment to the relevant budget, which is collected from taxpayers in accordance with the TCU", and the collection (fee, contribution) is a "mandatory payment to the relevant budget copes with the payers of fees, provided that they receive a special benefit, including as a result of committing in favor of such persons by state bodies, local governments, other authorized bodies and persons of legally significant actions" [10].

The obligation of citizens to pay taxes and fees in the manner and amounts prescribed by law, as well as the annual submission of declarations of their property and income to the tax inspectorate at the place of residence referred to in Article 67 of the Constitution of Ukraine [4].

Since the main revenue part of the budget is tax revenues, the direct performance of its functions by the state, ie the actual implementation of the planned budget expenditures, directly depends on the timeliness and completeness of taxes and fees paid by citizens of Ukraine. Therefore, there is a question of solving the problem of tax evasion in order to reduce losses from tax evasion schemes, increase revenues to the state budget, rational use of public funds, reduce debt and the need for additional credit to cover the budget deficit from international financial institutions.

We present the regulatory framework of Ukraine on tax evasion (Fig. 1).

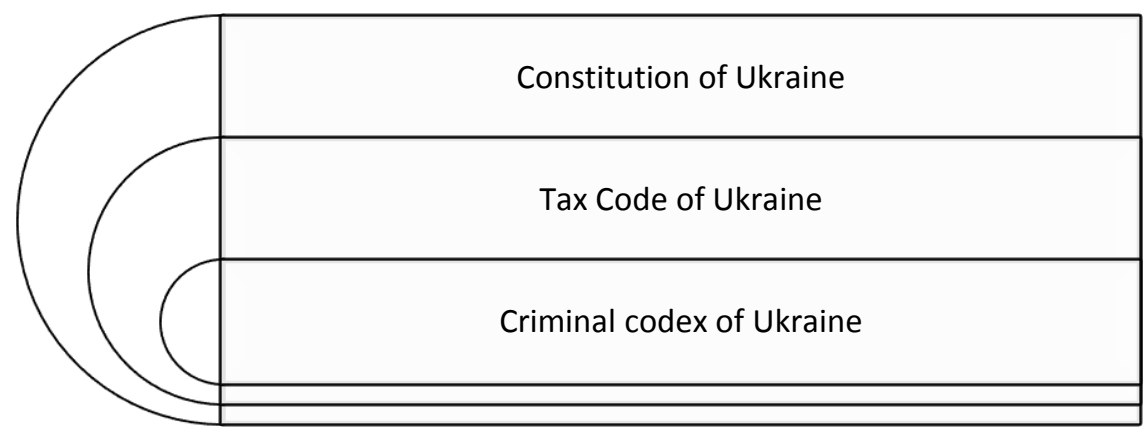

Figure 1 - Regulatory framework for tax evasion in Ukraine

Source: summarized by the authors $[4 ; 7 ; 10]$

On May 23, 2020, the Law of Ukraine "On Amendments to the Tax Code of Ukraine to improve tax administration, eliminate technical and logical inconsistencies in tax legislation" [2; 11], the purpose of which is:

- introduction of international tax control standards for all participants in international trade;
- implementation of the provisions of the Plan to counteract the practices of erosion of the tax base and withdrawal of profits from taxation;

- creating conditions for reforming the State Tax Service;

- improving the system of tax administration;

- expanding the capabilities of online services for payers. 
Liability for a criminal offense - tax evasion is provided by Article 212 of the Criminal Code of Ukraine (Fig. 2) [7].

Tax revenues to the state budget affect the state economy and the level of economic and, accordingly, national security of the state. Therefore, the full filling of the budget with this article and the fight against the shadow economy and, accordingly, tax evasion - is the main priority for the government.

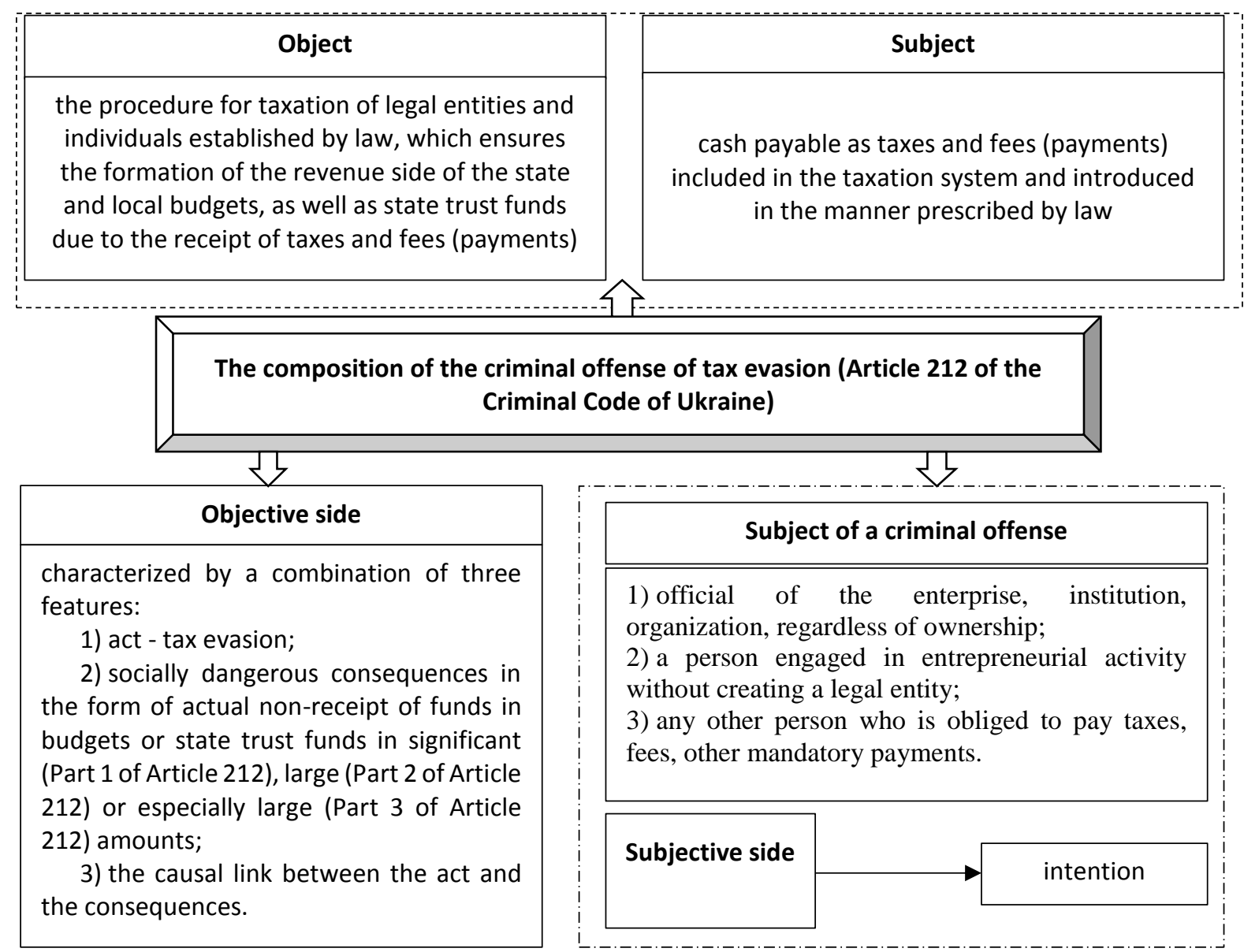

Figure 2 - Composition of a criminal offense - tax evasion under Article 212 of the Criminal Code of Ukraine

Source: presented and summarized by the authors on the basis [12]

Let's study the dynamics of revenues of the state and consolidated budgets of Ukraine during 2014-2020 (Table 1).

Table 1 Dynamics of revenues of the state and consolidated budgets of Ukraine in 2014-2020

\begin{tabular}{|c|c|c|c|c|c|c|c|c|}
\hline Indexes & 2014 & 2015 & 2016 & 2017 & 2018 & 2019 & 01.09 .2020 & $\begin{array}{c}\text { Dynamics } \\
\text { of the } \\
\text { indicator }\end{array}$ \\
\hline $\begin{array}{c}\text { Revenues of the } \\
\text { state budget of } \\
\text { Ukraine, UAH } \\
\text { million }\end{array}$ & 357084,2 & 534694,8 & 616274,8 & 793265 & 928108,3 & 998278,9 & 688695 & \\
\hline $\begin{array}{c}\text { Revenues of the } \\
\text { consolidated budget } \\
\text { of Ukraine, UAH } \\
\text { million }\end{array}$ & 456067,3 & 652031 & 782748,5 & 1016788,3 & 1184278,1 & 1289779,8 & 876392,5 & \\
\hline
\end{tabular}

Source: summarized by the authors on the basis [9]

Thus, the dynamics of revenues of the state and consolidated budgets of Ukraine during 2014-2019 tends to increase. The average revenue of the state budget during 2014-2019 is UAH 704,617.7 million, and the average revenue of the consolidated budget is $\mathrm{UAH}$ $896,948.8$ million. In 2019, state budget revenues increased compared to 2014 by UAH 641,194.7 million or $179.56 \%$, and the consolidated budget revenues - by UAH 
$833,712.5$ million or $180.81 \%$. As of September 1,2020 , $62.9 \%$ of the state budget revenues have been fulfilled.
Let's analyze the dynamics of tax revenues to the state and consolidated budgets of Ukraine in 2014-2020 (Fig. 3).

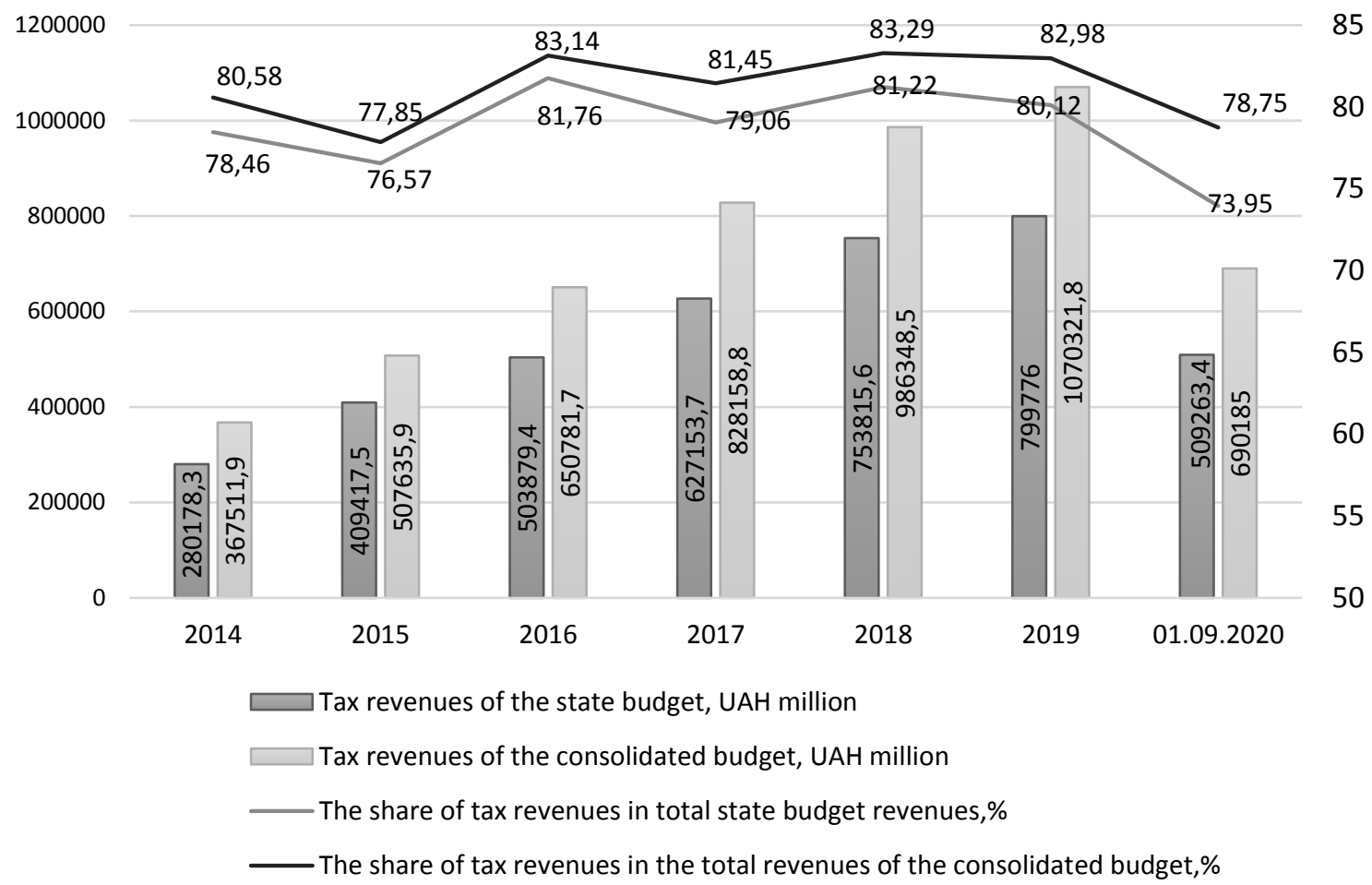

Figure 3 - Dynamics of tax revenues to the state and consolidated budgets of Ukraine in 2014-2020.

Source: presented by the authors on the basis of [9]

Thus, the dynamics of tax revenues to the state and consolidated budgets of Ukraine for the period 2014-2019 tends to increase. Using the data in table. 1 calculated the share of tax revenues to the state and consolidated budgets of Ukraine and presented their dynamics during the study period (2014-2020), which has a tendency to increase. The average share of tax revenues in the total state budget revenues for $2014-2019$ is $79.81 \%$, and the average share of tax revenues in the total revenues of the consolidated budget is $81.96 \%$. As of September 1, 2020, the state budget received UAH 509,263.4 million or $73.95 \%$ of all revenues from tax revenues, and $\mathrm{UAH}$ 609,185 million or $78.75 \%$ to the consolidated budget.

The figures for 2020 are currently lower than the reported figures for 2019, but the situation may change in the last 4 months. However, many scholars predict a reduction in tax revenues due to the situation in the country due to quarantine and the spread of the epidemic, which affected the functioning and results of business and entrepreneurship in the country.

Thus, tax revenues are the main revenue part of the budget of Ukraine. Therefore, their shortfall directly affects the level of economic security of the state, the economic situation in the country and the budget expenditures as a result. Due to the lack of tax revenues and consequent reduction of state budget revenues - the expenditure part of the state budget "suffers" and needs additional funds that will have to be attracted from various sources, as a result - increases the country's credit debt, dependence on creditors and their impact on the economy. In order to minimize such consequences, it is necessary to introduce an effective mechanism of the tax system, is the collection of taxes and fees.

Economist Volodymyr Dubrovsky, studying the shadow economy of Ukraine, singled out the rating of the main schemes of tax evasion and conditional losses from them for the budget of Ukraine (Fig. 4) [1].

Thus, the largest losses for the state budget are caused by: "gray imports", smuggling - UAH 70 billion and offshore schemes - UAH 65 billion. In total, the state budget of Ukraine loses only through these main types of tax evasion schemes - UAH 181 billion per year.

Let's determine the level of tax burden in Ukraine and present its dynamics for 2014-2019 (Table 2). 


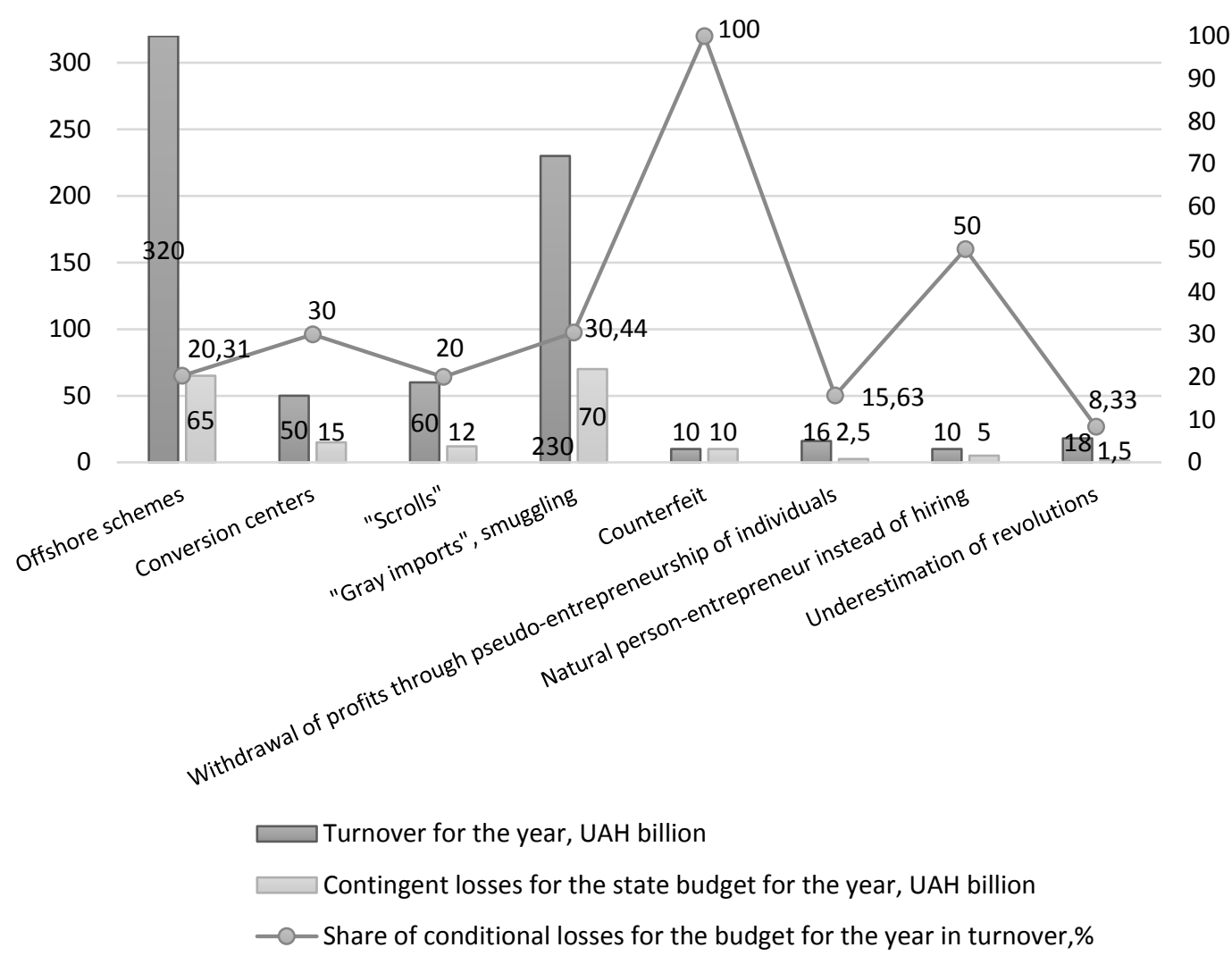

Figure 4 - Turnover of the main schemes of tax evasion for the year and contingent losses for the state budget Source: presented by the authors on the basis of [1]

Table 2 Dynamics of the level of tax burden in Ukraine in 2014-2019

\begin{tabular}{|c|c|c|c|}
\hline Years & $\begin{array}{c}\text { Nominal GDP, UAH } \\
\text { million }\end{array}$ & $\begin{array}{c}\text { Tax revenues, UAH } \\
\text { million }\end{array}$ & The level of tax burden, \% \\
\hline 2014 & 1566728 & 367511,9 & 23,46 \\
\hline 2015 & 1979458 & 507635,9 & 25,65 \\
\hline 2016 & 2383182 & 650781,7 & 27,31 \\
\hline 2017 & 2982920 & 828158,8 & 27,76 \\
\hline 2018 & 3558706 & 986348,5 & 27,72 \\
\hline 2019 & 3974564 & 1070321,8 & \\
\hline $\begin{array}{c}\text { Dynamics } \\
\text { of the } \\
\text { indicator }\end{array}$ & & & \\
\hline
\end{tabular}

Source: calculated and presented by the authors on the basis of [3; 9]

Analyzing the dynamics of the level of tax burden for the study period (2014-2019), we found that it has a variable trend. During 2014-2017 - there is a steady increase in the indicator, and from 2016 to 2017 - a slight decrease. The level of tax burden in Ukraine in the reporting year 2019 increased compared to the base year of 2014 by $3.47 \%$. In general, during this period, the figure averages almost a quarter of nominal GDP.

Therefore, as tax revenues are the main source of budget revenues, it is necessary to improve and update the regulatory framework, increase trust between taxpayers and the state, develop and implement a more effective mechanism for monitoring tax collection, fighting corruption and bureaucracy, and so on. All this will reduce the level of budget surplus, minimize the possibility of tax evasion, increase the revenue side of the budget, reduce accounts payable and the impact of creditors on the economy and political situation in the country.

Conclusions and perspectives of further research. In the process of studying the monitoring of the impact of tax evasion on the state budget of Ukraine, the following conclusions were made:

1. It is revealed that the dynamics of tax revenues to the state and consolidated budgets of Ukraine for the period 2014-2019 tends to increase. The average revenue of the state budget during 2014-2019 is UAH 704,617.7 million, and the average revenue of the consolidated 
budget is UAH 896,948.8 million. As of September 1, 2020, $62.9 \%$ of the state budget revenues have been fulfilled.

2. The dynamics of tax revenues to the state and consolidated budgets of Ukraine for the period 20142019, which has a tendency to increase, is analyzed.

3. The share of tax revenues to the state and consolidated budgets of Ukraine was calculated and presented their dynamics during the study period (20142020), which has a tendency to increase.

4. It was investigated that the largest losses for the state budget are caused by: "gray imports", smuggling - 70 billion UAH and offshore schemes - 65 billion UAH. In total, the state budget loses only through these basic types of tax evasion schemes - UAH 181 billion per year.
5. The level of tax burden in Ukraine is calculated and its dynamics in 2014-2019 are presented. In the reporting year 2019, the calculated indicator increased compared to the base year 2014 by $3.47 \%$. In general, during this period, the indicator occupies an average of almost a quarter of nominal GDP.

We are convinced that the introduction of effective mechanisms to combat tax evasion, adaptation to modern conditions of digitalization, improvement of tax legislation, fight against corruption, reform of the tax system - all this will help educate Ukrainian citizens as a tax responsible population, improve the country's economy, increase Ukraine's economic security.

\section{References:}

1. Dubrovsky, V. (2018). Rating of tax evasion schemes: what the Ukrainian budget loses the most. VoxUkraine. Retrieved from: https://voxukraine.org/en/rating-shem-uhilennya-vid-podatkiv-inachomu-ukrayinskij-byudzhet-vtrachaye-najbilshe/.

2. The law on combating tax evasion has been signed (2020). Legislation News (May 22). Retrieved from: https://uteka.ua/.

3. Zamaslo, O., Zubik, N. (2018). Analysis of losses of the state budget of Ukraine from tax evasion schemes. Priazovsky Economic Bulletin, 2 (07), 129-135. Retrieved from: http://pev.kpu.zp.ua/journals/2018/2_07_uk/25.pdf.

4. Constitution of Ukraine (1996) Order No. 254k / 96-VR, June 28. Retrieved from: https://zakon.rada.gov.ua/ laws/show/254\%D0\%BA/96-\%D0\%B2\%D1\%80.

5. Koryagina, T., Yakimenko, K. (2017). The problem of tax evasion and the consequences of this phenomenon for the budget of Ukraine. Young Scientist, 1 (41), 620-623.

6. Kramarenko, O. (2013). Ways of tax evasion in Ukraine. Scientific Notes, 23, 165-168.

7. Criminal Code of Ukraine (2001) Order No. 2341-III, April 5. Retrieved from: https://zakon.rada.gov.ua/laws/show/2341-14.

8. Melnyk, O. (2014). The main ways to evade taxes, fees and other mandatory payments. Fight against organized crime and corruption (theory and practice), 2 (33), 122-125.

9. Ministry of Finance. Retrieved from: http://www.minfin.gov.ua.

10. Tax Code of Ukraine dated (2010) No. 2755-VI, December 12. Retrieved from: https://zakon.rada.gov.ua/laws/show/2755-17.

11. On amendments to the Tax Code of Ukraine to improve tax administration, eliminate technical and logical inconsistencies in tax legislation (2020): Law Order No. 466-IX, January 16. Retrieved from: https://zakon.rada.gov.ua/laws/show/466-20.

12. Tax evasion: TOP-5 court decisions of 2020 (2020). LIGA360. Retrieved from: https://biz.ligazakon.net/ en/analitycs/197508_ukhilennya-vd-splati-podatkv-top-5-sudovikh-rshen-2020-roku/.

13. Yakimchuk, Yu. (2013). Tax evasion in Ukraine: features of the problem and ways to overcome it. Current Trends in Public Finance. Retrieved from: http://libfor.com/index.php?newsid=2205.

14. Poltorak, A. S. (2019). Shadow economy as an internal threat to financial security of Ukraine. Economic Journal of Odessa Polytechnic University, 3 (9), 104-111. DOI: 10.5281/zenodo.3805257.

Ця робота ліцензована Creative Commons Attribution 4.0 International License 